\title{
PERCEPÇÕES DE OUTRA CIDADE
}

Ana Paula Guida Tavares

guidatavares@uol.com.br

Aqui em Curitiba as pessoas não caminham, elas dirigem.

Eu caminho. Eu quase sempre caminho até o parque em que corro. Caminho sempre que posso. O caminho me move, não são apenas as pernas, os pés. O chão me move, ele vibra, sustenta e reverbera. Para mim, o percurso é, definitivamente, mais importante do que a celeridade com a qual se chega a algum lugar. E eu quero que o meu caminho seja calculado em passo, no máximo duplo, e não via hodômetro.

Em um ímpeto de perceber melhor a vida curitibana em que hoje me enquadro, e numa necessidade sensorial tamanha, caminhei até uma padaria que muito me agrada, na esperança de encontrar alguma coisa que me movimente (já que minha dança de hoje mixou).

E fui vivendo momentos sensoriais. Um sopro frio, típico do inverno daqui. Um cão vadio e silenciosamente resignado que me seguiu na esperança (feliz) de conquistar um naco do que eu viesse a beliscar. O som de muitos canos de descarga e de galhos que ventam sob e sobre fios. Os cheiros... do pão que assa no forno, do one million do carinha que estaciona ao lado, do morango que deita imponente sobre a torta branca.

Tudo isso é percepção. Isso tudo desperta instintos, momentos e pessoas à cinza das horas. Por exemplo, o vento frio de hoje me fez lembrar a Pont des Arts, em Paris. O cachorro evocou a lembrança afável de uma prima e uma amiga que, de alguma forma muito encantadora, sabem fazer e sentir poesia através dos bichanos. Os escapamentos são só irritantes, mas, ainda que não me façam pensar em nada especial, também causam "sensações" que, felizmente, passam rápido. Os galhos de árvores, quando tocam os fios, são como sinos dos ventos (que eu também não gosto). Algumas memórias são mais aprazíveis que outras, e detenho-me mais tempo nelas. $\mathrm{O}$ cheiro do pão lembra meu pai, o que me motiva saudade, o morango causa, em mim, a salivação do azedo...

Continuo, em passo simples, até encontrar o chão que procuro, visto que o destino não é nunca o mesmo, ainda que os locus sejam.

Entro na loja, sorrio para o haitiano que me atende em francês e tenta, assim como eu, se entender no absurdo da vida. "Bonsoir, fille souriant, você não veio ontem", ele diz. Eu acho que ele tem um brilho contumaz nos olhos. Ele sempre quer me oferecer algum pão, biscoito ou doce novo, ele nunca quer que eu compre o mesmo.

Acho que ele me entende. E eu aceito, conformada, a sua obstinação pelo novo. Sempre dá certo e hoje não foi diferente. Aceno e ele me responde com o mais confiante dos sorrisos. Pago e me encaminho para a saída quando me dou conta de que sei muito sobre ele: filhos, mulher, o antigo emprego como engenheiro civil, os idiomas que fala... mas não sei o seu nome!

Ele é Elinor Rigueur.

No caminho de volta penso em Elinor. Não me conformo com o seu atual trabalho, mas, condescendente, o Sr. Rigueur afirma que não há nada de ruim em trabalhar na padaria. Ele gosta do novo, ele gosta do que é diferente, ele gosta da padaria... Acho que entendo agora...

Tudo é sensorial, mas não nos damos conta de como podem ser intensas determinadas sensações. O sorriso de Elinor me leva pra casa, e eu sinto que, de alguma maneira, o meu também o arrasta para outro lugar. 